Kalem Eğitim ve İnsan Bilimleri Dergisi 2017, 7(2), 237-261, doi:10.23863/kalem.2017.86

Makale Gönderim Tarihi:20.10.2016

Makale Kabûl Tarihi:22.01.2017

\title{
60-72 Aylık Çocukların Yabancı Dillere Karşı İlgilerinin Çeşitli Değişkenlere Göre Farklılaşmasının İncelenmesi
}

\author{
Dr. Asude BALABAN-DAĞAL* \\ Marmara Üniversitesi, Atatürk Eğitim Fakültesi, Göztepe Yerleşkesi, Kadıköy / İstanbul / Türkiye, \\ asudebd@gmail.com, ORCID: 0000-0002-9527-5335

\section{Dr. Senem Seda ŞAHENK-ERKAN} \\ Marmara Üniversitesi, Yabancı Diller Bölümü, Göztepe Yerleşkesi, Kadıköy / İstanbul / Türkiye, \\ senemseda78@gmail.com, ORCID: 0000-0001-7861-430X
}

\section{Öz}

Bu çalışmanın amacı 60-72 aylık çocukların yabancı dillere olan ilgilerinin hangi değişkenlere göre farklılaştığını belirlemektir. Araştırmanın amacına ulaşabilmek için ilişkisel tarama modeli kullanılmıştır. Araştırmanın örneklemi; İstanbul Anadolu yakasının merkez ilçelerinde yabancı dil eğitimi veren, Millî Eğitim Bakanlığı'na bağlı resmî ve özel okul öncesi kurumlarına devam eden çocuklardan oluşmuştur. Araştırmaya 60-72 aylık 221 çocuk katılmıştır. Veri toplama aracı olarak okul öncesi dönem çocuklarının yabancı dillere karşı ilgilerini değerlendirebilmek için Şahenk-Erkan ve Balaban-Dağal'ın (2016) hazırladıkları 5'li likert tipi “60-72 Aylık Çocukların Yabancı Dillere Karşı İlgi Ölçeğì” kullanılmıştır. Verilerin analizinde nicel analiz yöntemlerinden varyans analizi, bağımsız grup $t$ testi ve ilişki analizi olarak pearson analiz yöntemi kullanılmıştır. Araştırma sonucunda okul öncesi dönem çocuklarının yabancı dillere karşı ilgilerinde cinsiyetlerinin ve okul türünün fark

* Sorumlu Yazar. Tel: +90 2163635486

(C) 2017 Kalem Eğitim ve Sağlık Hizmetleri Vakfı. Bütün Hakları Saklıdır. ～ISSN: 2146-5606 
yaratmadığı bulunmuştur. Ayrıca anne-babanın yabancı dil bilgi düzeylerinin, yaş gruplarının, okul dışında yabancı dil eğitimi alıp almamalarının ve haftalık yabancı dil ders saatlerinin çocukların yabancı dillere karşı ilgilerinde farklılık yarattığı gözlenmiştir.

Anahtar Kelimeler: 60-72 aylık çocuklar; Yabancı dil; İlgi; Okul öncesi dönem çocukları.

\title{
Examination of Variation of Interest in Foreign Languages among 60-72 Months Old Children
} According to Different Variables

\begin{abstract}
The purpose of this research was to find out the variables which differentiate the levels of interest of 60-72 months old children in foreign languages. Relational study with a descriptive model was used to achieve this purpose. The sample of the study was collected from public and private pre-schools operating under Turkish Ministry of Education, which are located in the central district on the Anatolian side of İstanbul, and which provide training in foreign languages. 60-72 months old 221 children participated in the research. A five option likert type scale called “The Scale for 60-72 Months Aged Children's Interest in Foreign Languages” developed by Balaban-Dağal and Şahenk-Erkan (2016) was used to measure the interest in foreign languages of the children. To analyze the data, besides using variance analysis and independent sample $t$ test as the means of quantitative analysis, Pearson Correlation Analysis was also used. The results of the research suggest that "gender" and "the type of school" do not make any difference on the pre-school children's interest in foreign languages. Furthermore, a statistically significant difference was determined among children's interest in foreign languages, parents' foreign language level, children's age group, out of school training of foreign language and foreign language lesson hours in a week.
\end{abstract}

Keywords: 60-72 months old children; Foreign language; Interest; Pre-school children. 


\section{Extended Summary}

\section{Purpose}

The purpose of the research is to determine the differentiation of interest of children between ages of 60-72 months towards foreign languages based on their gender, age group, foreign language level of parents and weekly hours of studying foreign language.

\section{Method}

In so far as variables affecting the interest of children aged 60-72 months towards foreign languages are examined in this study, the study is designed in the relational screening model.

\section{Sampling}

The sampling of the research is formed of 221 children at the ages between 60-72 months old who study in official and private pre-school education institutions located in central districts of Anatolian Side, İstanbul, affiliated to Ministry of National Education and providing foreign language education

\section{Data Collection Tools}

The "The Scale for 60-72 Months Aged Children's Interest in Foreign Languages” prepared by Şahenk-Erkan and Balaban-Dağal was used to evaluate the interest of pre-school children towards foreign languages. The scale of the likert type of 5 consisting of 17 items is formed of two dimensions as "determination" and "willingness". Internal consistency of the dimension "determination” was found to be 97 and Internal consistency of "willingness" was found to be 73 (Balaban-Dağal and Şahenk-Erkan, 2016).

\section{Data Collection Process}

Before the data collection process, the permit was obtained from Provincial Directorate of National Education to conduct research in the pre-school education institutions. The data collection process was carried out by obtaining permits from school administrators and teachers by visiting the schools determined in accordance with the sampling methods by researchers. In the process of data collection, the teachers who took part in foreign language education activities were asked to list which children could reply the queries and they are asked to fill out the forms appropriately. It takes approximately 10 minutes to complete the forms. 


\section{Analysis of Data}

The ANOVA, independent group $t$ test and Pearson analysis were used regarding differentiation of interest of 60-72 month aged children who study in pre-school institutions towards foreign language based on gender, age groups, school culture foreign language education outside the school, level of foreign language knowledge of parents and hours of weekly foreign language education. When the ANOVA results were significant, a Scheffe analysis was conducted to predict the direction of the difference.

\section{Results}

The results of the research suggest that "gender" and "the type of school" did not make any differences on the pre-school children's interest in foreign languages. Furthermore, a statistically significant difference was determined among children's interest in foreign languages, parents' foreign language level, children's age group, out of school training of foreign language and foreign language lesson hours in a week.

\section{Discussion}

In this study, it was researched whether interest of 60-72 month aged children who study in pre-school institutions towards foreign language differ according to gender, age groups, school culture foreign language education outside the school, level of foreign language knowledge of parents and hours of weekly foreign language education.

It has been determined in the study that there was no difference between the foreign language and gender variables. As a matter of fact, Çakan (2005) has also found that foreign language education did not differentiate between the genders in the research he conducted with elementary school students.

When interest of children towards foreign languages according to the age groups was examined a significant difference was found in both the total scale score and the willingness and determination subscales in favor of the 6 years old children groups. Based on this fact, it can be said that interest of 6 years old children towards foreign languages was higher than in 5 years children group. Accordingly, it can be said that interest of children towards knowledge of foreign languages increase with their ages. As a matter of fact, in their research conducted with pre-school children: Kearney and Barbour (2015), Adzija and Sindik (2014) and Ekizoğlu and Ekizoğlu (2011) found that skills and knowledge of children aged 3, 4, 5 and 6 getting pre-school 
foreign language education improved positively as their ages increase.

When the results of differentiation of interest of children towards foreign languages according to school type they attend were assessed, no difference was found in the scale total score and willingness and determination subscales. This situation can be interpreted as the fact that whether the child study in public school or the private school and influence interest of children towards foreign languages. The fact that all of the teachers of the children who work in public schools or in private schools are graduated from similar schools and in fact lack of any difference in terms of the teachers can be explained as the reason why there is no difference in the interest of these children.

When the results of the difference of children's interest in foreign language learning in terms of studying foreign language outside the school were evaluated, it was found that there was a significant difference in terms of total scale, determination and willingness dimensions in the direction getting foreign language education outside the school as well. In this case, it can be said that interest of children who are learning foreign languages outside the school towards foreign language is more than other children or that foreign language education outside the school improve children's interest towards foreign languages. When the research conducted here and the other researches are evaluated together, it can be said that as time spent for foreign language outside increases, the interest of the children to learn a new language also increases and this leads to an increase in the level of foreign language knowledge and skills.

When the interest of children towards foreign languages according to level of foreign language of the father was assessed it was determined that foreign language level of father creates difference in the total scale score, willingness and determination dimensions of interest of foreign language level of the children. In this case, the better the level of foreign language of father is, the higher the interest of children in foreign languages gets. In the researchs conducted by Griva, Semogloua and Geladari (2010) and Adzija and Sindik (2014), it was found that as the foreign language level of the father increases, the foreign language knowledge and skills of the children also increase.

When the interest of children towards foreign languages according to level of foreign language of the mother was assessed it was determined that 
foreign language level of mother creates difference in the total scale score, willingness and determination dimensions of interest of foreign language level of the children. Good foreign language level of mother improves interest of children for foreign language and willingness and determination of children towards learning foreign language. Similarly, Lazăr (2014) found that knowledge and skill levels of children in learning a foreign language who received foreign language education before school create a significant difference between language levels of their mothers.

A positive relationship was found between the hours spent for foreign language study in school and the interest of foreign language of children. Increasing the hours of foreign language activity of children at this point also increases the interest of children to foreign languages.

\section{Conclusion and Recommendations}

Based on the findings related to level of foreign language of parents, it can be suggested to practitioners to support the efforts to learn a new language no matter how old their parents are. Based on the finding that foreign language education outside school increases interest of children in learning foreign languages it can also be said that parents should encourage their children to receive foreign language education or expose their children to foreign languages outside the school. On the basis of the increase in the number of hours foreign language studied in the school and the increase in interest in foreign language learning, it may be suggested to increase the numbers of hours foreign language studied by school administrators and officials.

\section{Giriş}

Günümüzde dünya ülkelerinin birbirleriyle olan yakın ilişkileri ve etkileşimleri yabancı dil öğrenmeye duyulan gereksinimi de arttırmaktadır. Kurulan iletişimin sağlıklı olabilmesi, yanlış anlaşılmalardan uzak olması ancak doğru dil kullanımıyla olmaktadır. Ana dilini ve diğer dilleri doğru kullanabilen bireyler karşısındaki kişilerle de doğru iletişim kurabilirler, yabancı dile hâkim olan bireyler diğer ülkelerde yaşayan kişilerle de doğru iletişim kurarak sağlıklı etkileşimlerde bulunabilirler.

Günümüzde küreselleşme boyutunda dünya ile bütünleşme ve bütün ülkelerin diğer ülkelerle ticarî, ekonomik, politik, siyasî vb. birçok alanda beraber olması gerekliliği ve zorunluluğunun etkisiyle yabancı dil eğitimi ve öğretiminin önemi her geçen gün gittikçe artmaktadır (Özcan, 2008). Bu 
durum tüm bireylerin kişisel, meslekî ve sosyal hayatta güçlü ilişkiler kurabilmesi için, bir veya birden çok dili etkin ve akıcı bir biçimde konuşabilmesini teşvik etmektedir.

Yabancı dil öğretimi her yaşta ve her seviyede uygulanabilen; fakat oldukça ciddiye alınması gereken bir süreçtir (Genç-İlter ve Er, 2007). Kaynaklar yabancı dil eğitimi almada kritik dönemlerden bahsetmektedir. İnsan beyninde, 18 milyar kadar nöron öğrenme işi ile uğraşır. Beyinde oluşmaya başlayıp yerleşik düzene geçen işitme-konuşma-dinleme-anlama merkezleri buluğ çağı süresince beynin sağ veya sol yarımküresine odaklanır (lateralization); odaklanma buluğ çağı sonrasında tamamlanır. Bu nedenle bazı kişiler sol yarımküre denetimli (cerebral dominance), bazıları da sağ yarımküre denetimli olurlar. Lenneberg'e göre (1967, akt; Demirezen, 2003), sağ veya sol küresel denetim, ikinci yaşta oluşmaya başlar ve 10-12. yaşta oluşum ve odaklanma tamamlanır. Sağ elini kullananlarda sol beyin yarımküresine, sol elini kullananlarda sol beyin yarımküresine işitme-konuşma-dinleme-anlama beceri odakları kalıcı olarak yerleşir. Bu kalıcı yerleşim buluğ çağı sonunda yaklaşık en geç 13. yaşta tamamlanır. İşte, bu odaklanmanın tamamlanması bitmeden bir yabancı dili öğrenmeye başlayan öğrenciler, o yabancı dili hiç zorlanmadan rahatlıkla o dili anadili olarak yazan konuşan kişilerin beceri düzeyinde öğrenebilirler (Demirezen, 2003). Bu bağlamda 21. yüzyılda yabancı dilin öneminin artmasıyla birlikte, erken yaşta yabancı dil eğitim ve öğretimine daha fazla yer verilmektedir. Birçok ulusal ve uluslararası araştırmada da okul öncesi dönemde yabancı dil eğitim-öğretiminin bireyin hem istek hem de motivasyon durumunda olumlu yansımalar oluşturduğu vurgulanmaktadır. Bununla birlikte yabancı dil eğitiminin bireyin telaffuz ve konuşma becerileri üzerine de olumlu etkileri olduğu doğrulanmaktadır (Akdoğan, 2004; Anşin, 2006; Genç-İlter ve Er, 2007; Halliwell, 1993; Kara, 2004; Gardner ve Lambert, 1972; Mirici, 2001; Mirici, Metin, Efe ve Akınc1, 2002; Roth, 1998; Sevinç, 2003; Yazıc1, 2003).

Yabancı dil eğitiminde en önemli noktalardan birisi de elbette yeni bir şeyi öğrenirken öğrenilen şeye karşı duyulan ilgidir. Nitekim Ainley (1998), Renninger (2000), Renninger ve Wozniak (1985), Schiefele (1996) ve Schiefele, Krapp ve Winteler (1992) yapmış oldukları araştırmalarda ilginin bilişsel süreçlerle de bağlantılı olduğunu ifade etmişlerdir (akt; Ainley, Hidi ve Berndorff, 2002). Çocuklar hatta yetişkinler bile istek ve ilgi duydukları bilgileri, konuları, alanları daha kolay öğrenirler. Küçükoğlu, Kaya ve Turan 
(2010) öğrenme yöneliminin, bireyin öğrenme sürecinde öğreneceği konuyu tam anlamıla öğrenmek istemesiyle ilgili olduğunu ifade etmişlerdir. Öğrenme yönelimini benimseyen bireyler, yeni bilgiler öğrenmeye meraklı, anlayışlarını ve yeterliklerini geliştirmeye açıktırlar. Bu yönelimdeki bir öğrenci, yeteneklerini geliştirmek için çaba harcar, çaba gerektiren faaliyetleri seçmeye isteklidir, hatalarına rağmen pes etmez ve hatalarını öğrenme sürecinin doğal bir parçası olarak görür (Akın ve Arslan, 2014). Bu durum öğrenmede iki olguyu ortaya çıkarmaktadır; öğrenme konusunda istekli olma ve öğrenme konusunda kararlı olma. Duckworth, Peterson, Matthews ve Kelly (2007), kararlılığı davranışlarda süreklilik sergileme ve uzun vadeli hedefler için azimli olma şeklinde tanımlamışlardır (akt; Akın ve Arslan, 2014). Yabancı dil eğitiminde önemli görülen ve ilgi boyutunda değerlendirilen diğer boyutlar ise kararlılık ve istekliliktir. Bunun için yabancı dil öğrenmeye kararlı olan bireylerin öncelikle kendilerine öğrenme hedefi koymaları gerektiği söylenebilir. Bireyin yabancı dile yönelik var olan istek ve ilgisinin onu başarıya götüren en temel anahtar olduğu kesinlikle unutulmamalıdır (Akgöz ve Gürsoy, 2014; Soyupek, 2007; Uslu ve Özpek, 2014).

Erken çocukluk döneminde yabancı dil ile ilgili çalışmalar motivasyon konusunda sınırlı kalmakla birlikte mevcut çalışmalar, genellikle yabancı dil eğitiminin çocuklara oyun ve görsel materyallerle verilmesinin onların motivasyonlarında, ilgilerinde ve aynı zamanda istek ve kararlılıklarında olumlu gelişmeler olduğunu göstermektedir (Bernard, 2010; Brumen, 2011; MacInytre ve Blackie, 2012; Dörnyei, 1999; Fisher, 1990; Mihaljevic-Djigunovic, 2012; Oxford ve Shearin, 1994; Juriševič ve Pižorn, 2013; Schmidt, Boraie ve Kassabgy, 1996). Yukarıda da bahsedildiği gibi küçük çocukların erken yaşlarda yabancı dil öğrenmeye ilgilerinin çekilmesi, onların kritik dönemlerini yakalayarak öğrenme ve ilgilerini çekebilme açısından çok önemlidir. Ancak öncelikle küçük çocukların erken yaşlarda yabancı dillere olan ilgilerini nelerin etkilediğinin ortaya konması gerekmektedir. Çocukların ilgilerini etkileyen etmenlerin ortaya konması eğitim programlarının düzenlemesi açısından da önemlidir. Bu noktada araştırmanın amacı; 60-72 aylık çocukların yabancı dillere olan ilgilerini cinsiyetlerine, yaş gruplarına, anne-babanın yabancı dil düzeyine, haftada aldığg yabancı dil saat aralığına göre farklılaşmasını tespit etmektir. 


\section{Yöntem}

Bu bölümde araştırmanın modeli, örneklemi, veri toplama araçları ve veri toplama süreci hakkında bilgi verilmiştir.

\section{Araştırma Modeli}

$\mathrm{Bu}$ araştırmada nicel analiz yöntemlerinden ilişkisel tarama modeli kullanılmıştır. İlişkisel tarama modelleri, iki veya daha çok sayıdaki değişken arasında birlikte değişim varlığını ve/veya derecesini belirlemeyi amaçlamaktadır (Karasar, 2014). Bu çalışmada da 60-72 aylık çocukların yabancı dillere olan ilgilerini etkileyen değişkenler incelendiğinden araştırma ilişkisel tarama modelinde tasarlanmıştır.

\section{Örneklem}

Araştırmanın örneklemi; İstanbul Anadolu yakasının merkez ilçelerinde yabancı dil eğitimi veren Millî Eğitim Bakanlığı'na bağlı resmî ve özel okul öncesi kurumlarına devam eden 60-72 aylık toplam 221 çocuktan oluşmaktadır. Örneklem belirlenirken Anadolu yakasında yer alan merkez ilçeler tabakalı örnekleme modeli ile değerlendirilmiştir. Tabakalı örneklemede, evren tabaka ismi verilen birbirinden bağımsız gruplara ayrılır ve her bir gruptan tesadüfî bir örneklem seçilir (Christensen, Johnson ve Turner, 2015, s.166-167). Bu bağlamda her bir merkez ilçeden yabancı dil eğitimi veren iki okul tesadüfî yöntem ile belirlenmiştir. Böylece Anadolu yakasında yer alan merkez ilçelerdeki yabancı dil eğitimi veren okulların örnekleme girme şans1 eşit olarak belirlenmiştir. Okul öncesi eğitim kurumuna devam eden çocukların seçiminde ise okulların idarecileri ve öğretmenleriyle görüşülerek, anakütle ve örnek birim sayıları ile orantılı eşit aralıklarla birimlerin çekilerek örneğin düzenlendiği sistematik örnekleme yöntemi (Turanlı ve Güriş, 2010, s.11) kullanılmıştır. Sistematik örnekleme yaparken sınıf listeleri göz önüne alınmış, araştırmacının ilk sayıyı rastgele olmak koşuluyla belirlediği numaralardaki öğrenciler için öğretmen değerlendirmesi alınmıştır. Her bir öğretmenden sınıfındaki 10 öğrenci için değerlendirme yapması istenmiştir. Öğretmenlerin bütün çocuklar için form doldurmasındaki zorluk ve öğrenci seçimindeki yanlılığı ortadan kaldırmak adına çocukların seçiminde sistematik örnekleme yönteminin kullanımı uygun görülmüştür. Çalışmaya katılan 60-65 aylık çocuklar 5 yaş grubu, 66-72 aylık çocuklar 6 yaş olarak değerlendirmeye alınmıştır.

Tablo 1'de görüleceği gibi okul öncesi kuruma devam eden çocukların \%51.6'sı devlet okuluna, \%48.4'ü özel okula devam etmektedir. Araştırmaya 
katılan çocukların \%51.1'i kız, \%48.9'u erkektir, \%60.2 çocuk 5 yaş grubunda, \%39.8 çocuk ise 6 yaş grubundadır.

Tablo 1. Çalışmaya Katılan Çocukların Demografik Verilere Göre Dağılımı

\begin{tabular}{llcc}
\hline & Değişkenler & f & \% \\
\hline \multirow{2}{*}{ Okul Türü } & Devlet & 114 & 51.6 \\
& Özel & 107 & 48.4 \\
\hline \multirow{2}{*}{ Cinsiyet } & K1z & 113 & 51.1 \\
& Erkek & 108 & 48.9 \\
\hline \multirow{2}{*}{ Yaş Grubu } & 5 Yaş & 133 & 60.2 \\
& 6 Yaş & 88 & 39.8 \\
\hline
\end{tabular}

\section{Veri Toplama Araçları}

Okul öncesi dönem çocuklarının yabancı dillere karşı ilgilerini değerlendirebilmek için Balaban-Dağal ve Şahenk-Erkan (2016) tarafından hazırlanan “60-72 Aylık Çocukların Yabancı Dillere Karşı İlgi Ölçeği” kullanılmıştır. 17 maddeden oluşan 5'li likert tipindeki ölçek "kararlılık” ve "isteklilik" olarak iki boyuttan oluşmaktadır. "Kararlılık” boyutunun iç tutarlılığı .97; "isteklilik" boyutunun iç tutarlılığı ise .73 bulunmuştur (Balaban-Dağal ve Şahenk-Erkan, 2016).

\section{Veri Toplama Süreci}

Verilerin toplanması merhalesine geçilmeden önce il millî eğitim müdürlügünden okul öncesi eğitim kurumlarında araştırma yapma izni alınmıştır. Araştırmacıların örnekleme yöntemlerine uygun olarak belirledikleri okullara bizzat gidilerek okul yöneticilerinden ve öğretmenlerden izin alınmak suretiyle veri toplama süreci gerçekleştirilmiştir. Veri toplama sürecinde yabancı dil eğitimi etkinliklerinde görev alan öğretmenlere hangi çocuklara uygulama yapacaklarının listesi verilerek kendilerinden formları uygun şekilde doldurmaları rica edilmiştir. Formların doldurulması yaklaşık olarak 10 dakika sürmektedir.

\section{Bulgular}

Bu bölümde okul öncesi kuruma devam eden 60-72 aylık çocukların yabancı dillere karşı ilgilerinin cinsiyetlerine, yaş gruplarına, okul türüne, okul dışında yabancı dil eğitimi alma durumlarına, anne-babanın yabancı dil bilgi düzeyine ve okulda verilen yabancı dil eğitimi saatlerine göre farkl1laşmasına ilişkin analiz tablolarına yer verilmiştir. 
Tablo 2. 60-72 Aylık Çocukların Yabancı Dillere Karşı İlgilerinin Cinsiyetlerine Göre Bağımsız Grup $t$ Testi

\begin{tabular}{llcccccc}
\hline & Cinsiyet & $\mathbf{N}$ & Ort. & ss & t & sd & $\boldsymbol{p}$ \\
\hline Toplam & K1z & 113 & 3.7095 & .82249 & \multirow{2}{*}{289} & \multirow{2}{*}{218.813} & .773 \\
& Erkek & 108 & 3.6786 & .76326 & & & \\
\hline Kararl111k & K1z & 113 & 3.6833 & .88743 & \multirow{2}{*}{013} & \multirow{2}{*}{218.548} & .990 \\
(Faktör 1) & Erkek & 108 & 3.6819 & .81021 & & & \\
\hline İsteklilik & K1z & 113 & 3.8319 & .75609 & \multirow{2}{*}{1.607} & \multirow{2}{*}{219} & .109 \\
(Faktör 2) & Erkek & 108 & 3.6636 & .80044 & & & \\
\hline
\end{tabular}

Tablo 2'ye göre, 60-72 aylık okul öncesi devam eden çocukların yabancı dillere karşı ilgileri cinsiyetlerine göre toplam puan açısından, kararlılık boyutunda ve isteklilik boyutunda değişmemektedir. Bu durumda $60-72$ aylık çocukların yabancı dillere karşı ilgilerinin cinsiyet açısından farklılaşmadığ 1 bulunmuştur $(p>.05)$. Bu bağlamda, çocukların yabancı dillere karşı ilgilerini cinsiyetlerinin etkilemediği söylenebilir.

Tablo 3. 60-72 Aylık Çocukların Yabancı Dillere Karşı İlgilerinin Yaşlarına Göre Bağımsız Grup $t$ Testi

\begin{tabular}{lccccccc}
\hline & Yaş & $\mathbf{N}$ & Ort. & ss & t & sd & $\boldsymbol{p}$ \\
\hline Toplam & 5 yaş & 133 & 3.4295 & .84098 & -7.391 & 216.433 & .000 \\
& 6 yaş & 88 & 4.0949 & .49533 & & & \\
\hline Kararlılık & 5 yaş & 133 & 3.3818 & .91945 & -8.179 & 201.877 & .000 \\
(Faktör 1) & 6 yaş & 88 & 4.1372 & .43727 & & & \\
\hline İsteklilik & 5 yaş & 133 & 3.6516 & .68148 & -2.194 & 151.870 & .030 \\
(Faktör 2) & 6 yaş & 88 & 3.8977 & .89465 & & & \\
\hline
\end{tabular}

${ }^{*} p<0.05$

Tablo 3'e göre, 60-72 aylık okul öncesi devam eden çocukların yabancı dillere karşı ilgileri toplam puan ve alt faktörlere (f1: kararlılık, f2: isteklilik) göre anlamlı bir farkl11ık göstermektedir (toplam p:.000; $p<0.05$; f1: $p: .000$; $p<0.05$; f2: $p: .000 ; p<0.05$ ). Bu sonuca göre, yabanc1 dil eğitimi alan 6 yaşındaki çocukların 5 yaşındakilere göre yabancı dillere karşı ilgilerinin daha fazla olduğu belirlenmiştir (toplam ort. 5 yaş: 3.4295; toplam ort. 6 yaş: 4.0949).

Benzer şekilde çocukların yabancı dillere karşı ilgileri kararlılık ve isteklilik boyutlarında incelendiğinde 6 yaş grubundaki çocukların 5 yaş gru- 
bundaki çocuklara göre daha fazla ilgili olduğu gözlemlenmektedir (flort. 5 yaş: 3.3818; f1ort. 6 yaş: 4.1372; f2ort. 5 yaş: 3.6516; f2ort. 6 yaş: 3.8977). Bu durumda okul öncesine devam eden çocukların yaşları büyüdükçe yabancı dillere karşı ilgilerinin arttığı söylenebilir.

Tablo 4. 60-72 Aylık Çocukların Yabancı Dillere Karşı İlgilerine Okul Türüne Göre Bağımsız Grup $t$ Testi

\begin{tabular}{llcccccc}
\hline & Okul Türü & $\mathbf{N}$ & Ort. & ss & t & sd & $\boldsymbol{p}$ \\
\hline Toplam & Devlet & 114 & 63.043 & 14.017 & \multirow{2}{*}{271} & \multirow{2}{*}{218.933} & .787 \\
& Özel & 107 & 62.551 & 12.925 & \multirow{2}{*}{.714} & & \\
\hline Kararlılık & Devlet & 114 & 51.517 & 12.373 & \multirow{2}{*}{050} & \multirow{2}{*}{218.921} & .960 \\
(f1) & Özel & 107 & 51.598 & 11.390 & & & \\
\hline İsteklilik & Devlet & 114 & 11.526 & 2.285 & \multirow{2}{*}{1.827} & \multirow{2}{*}{219} & .069 \\
(f2) & Özel & 107 & 10.953 & 2.376 & & & \\
\hline
\end{tabular}

Tablo 4'e göre, 60-72 aylık okul öncesi kuruma devam eden çocukların yabanc1 dillere karşı ilgileri devam ettikleri okul türüne göre toplam puan açısından, kararlılık boyutunda ve isteklilik boyutunda farklılık göstermemektedir. 60-72 aylık çocukların yabancı dillere karşı ilgilerinin okul türü açısından farklılaşmadığı bulunmuştur ( $p>.05)$. Bu durumda çocukların devam ettikleri okulun özel ya da devlet okulu olması çocukların yabancı dillere ilişkin ilgilerinde farklılık yaratmadığı, çocukların yabancı dile olan ilgilerini etkileyen farklı bağımsız değişkenlerin olduğu ifade edilebilir.

Tablo 5. 60-72 Aylık Çocukların Yabancı Dillere Karşı İlgilerinin Okul Dışında Yabancı Dil Eğitimi Almalarına Göre Bağımsız Grup $t$ Testi

\begin{tabular}{llcccccc}
\hline & $\begin{array}{l}\text { Okul Diss. Yab. } \\
\text { Dil Eğt. Alma }\end{array}$ & N & Ort. & ss & t & sd & p \\
\hline Toplam & Evet & 92 & 4.3018 & .50978 & 13.174 & 217.754 & .000 \\
& Hayır & 129 & 3.2613 & .66360 & & & \\
\hline Kararlılık & Evet & 92 & 4.2655 & .52278 & 11.295 & 217.871 & .000 \\
(Faktör 1) & Hayır & 129 & 3.2669 & .79065 & & & \\
\hline İsteklilik & Evet & 92 & 4.4710 & .51153 & 18.304 & 185.788 & .000 \\
(Faktör 2) & Hayır & 129 & 3.2351 & .47030 & & & \\
\hline
\end{tabular}

Tablo 5'e göre, 60-72 aylık çocukların okul dışında yabancı dil eğitimi almaları konusundaki yabancı dillere karşı ilgileri değerlendirildiğinde toplam puanda, kararlılık ve isteklilik boyutlarında anlamlı bir farklılık tespit edilmiştir (Toplam=.000; $\mathrm{f}_{1}=.000 ; \mathrm{f}_{2}=.000$ ). Elde edilen bulgulara göre, ço- 
cukların yabancı dillere karşı ilgileri okul dışında yabancı dil eğitimi alanlar lehinedir ( Toplam ort. evet $=4.3018$, Toplam ort. hayir $=3.2613 ; \mathrm{f}_{1 \text { evet }}=4.2655, \mathrm{f}_{\text {1hayr }}=$ 3.2669; $\left.\mathrm{f}_{2 \text { evet }}=4.4710, \mathrm{f}_{2 \mathrm{hayr}}=3.2351\right)$. Bu durumda okul dişında yabancı dil eğitimi alan çocukların yabancı dillere karşı ilgilerinin daha fazla olduğu ya da yabancı dil eğitimini dışarıdan bir kaynakla aldırmanın çocukların yabancı dillere karşı ilgilerini arttırdığı söylenebilir.

Tablo 6. 60-72 Aylık Çocukların Yabancı Dillere Karşı İlgilerinin Baba Yabancı Dil Düzeylerine İlişskin ANOVA Sonuçları

\begin{tabular}{llccccc}
\hline $\begin{array}{l}\text { Baba Yabancl } \\
\text { Dil Düzeyi }\end{array}$ & $\begin{array}{l}\text { Varyansın } \\
\text { Kaynağı }\end{array}$ & KT & sd & KO & F & $\boldsymbol{p}$ \\
\hline Toplam & Gruplar aras1 & 21.991 & 2 & 10.995 & 20.635 & .000 \\
& Gruplar içi & 116.164 & 218 & .533 & & \\
& Toplam & 138.154 & 220 & & & \\
\hline Kararlılık & Gruplar aras1 & 26.153 & 2 & 13.077 & 21.549 & .000 \\
(Faktör 1) & Gruplar içi & 132.288 & 218 & .607 & & \\
& Toplam & 158.442 & 220 & & & \\
\hline İsteklilik & Gruplar aras1 & 8.994 & 2 & 4.497 & 7.833 & .001 \\
(Faktör 2) & Gruplar içi & 125.152 & 218 & .574 & & \\
& Toplam & 134.146 & 220 & & & \\
\hline
\end{tabular}

Tablo 6'ya göre, 60-72 aylık okul öncesine devam eden çocukların yabancı dillere karşı ilgilerinin baba yabancı dil düzeylerine göre varyans analizi sonuçları incelendiğinde hem toplam puanlarda hem de alt faktörler (faktör 1 kararlılık ve faktör 2 isteklilik) boyutunda anlamlı bir farklılık belirlenmiştir (Ft:20.635; $p<0.05$; F1:21.549; $p<0.05$; F2:7.833; $p<0.05$ ). Bu bağlamda 60-72 aylık çocukların yabancı dillere karşı ilgilerinin baba yabancı dil düzeylerine göre varyans analizi tablosu incelendiğinde, okul öncesine devam eden çocukların baba yabancı dil düzeyleriyle yabancı dile karşı ilgilerinin toplam puanlarda, kararlılık ve isteklilik boyutlarında farklılık tespit edilmiştir. Bu durumda baba yabancı dil düzeyine ilişkin farkın yönünü tespit edebilmek için Scheffe analizi yapılmıştır.

Tablo 7'de görüleceği gibi, araştırmaya katılan çocukların yabancı dillere karşı ilgileri, baba yabancı dil düzeylerine göre değerlendirildiğinde puan ortalamaları Scheffee testi ile analiz edildiğinde babası başlangıç seviyesinde yabancı dile sahip çocuklarla babası iyi düzeye sahip çocuklar arasında babası iyi yabancı dil düzeyine sahip babaların çocukların lehine farkl11ık tespit edilmiştir $\left(\mathrm{X}_{\text {ortiyi: }}\right.$-15.56232; $\left.p<.05\right)$. 
Tablo 7. 60-72 Aylık Çocukların Yabancı Dillere Karşı İlgilerinin Baba Yabancı Dil Düzeylerine İlişkin Ft, F1 (Kararlılık) ve F2 (İsteklilik) Boyutlarında Scheffe Analizi

\begin{tabular}{|c|c|c|c|c|c|}
\hline $\begin{array}{l}\text { Baba Yabancı } \\
\text { Dil Düzeyi }\end{array}$ & (I) aylık & (J) aylık & $\begin{array}{c}\text { Ort. Fark } \\
\text { (I-J) }\end{array}$ & Std. Hata & $p$ \\
\hline \multirow[t]{6}{*}{ Toplam } & \multirow[t]{2}{*}{ Başlangıç } & Orta & -.32209 & .15972 & .133 \\
\hline & & İyi & $-.91543^{*}$ & .17040 & $.000 *$ \\
\hline & \multirow[t]{2}{*}{ Orta } & Başlangıç & .32209 & .15972 & .133 \\
\hline & & İyi & $-.59334^{*}$ & 10917 & $.000 *$ \\
\hline & \multirow[t]{2}{*}{ İyi } & Başlangıç & $.91543^{*}$ & .17040 & $.000 *$ \\
\hline & & Orta & $.59334^{*}$ & .10917 & $.000 *$ \\
\hline \multirow{6}{*}{$\begin{array}{l}\text { Kararlılık } \\
\text { (Faktör 1) }\end{array}$} & \multirow[t]{2}{*}{ Başlangıç } & Orta & -.29645 & .17044 & .223 \\
\hline & & İyi & $-.96352^{*}$ & 18185 & $.000 *$ \\
\hline & \multirow[t]{2}{*}{ Orta } & Başlangıç & .29645 & .17044 & .223 \\
\hline & & İyi & $-.66707^{*}$ & .11650 & $.000 *$ \\
\hline & \multirow[t]{2}{*}{ İyi } & Başlangıç & $.96352^{*}$ & 18185 & $.000 *$ \\
\hline & & Orta & $.66707^{*}$ & .11650 & $.000 *$ \\
\hline \multirow{6}{*}{$\begin{array}{l}\text { İsteklilik } \\
\text { (Faktör 2) }\end{array}$} & \multirow[t]{2}{*}{ Başlangıç } & Orta & $-.44178^{*}$ & .16578 & $.030 *$ \\
\hline & & İyi & $-.69101^{*}$ & .17687 & $.001 *$ \\
\hline & \multirow[t]{2}{*}{ Orta } & Başlangıç & $.44178^{*}$ & .16578 & $.030 *$ \\
\hline & & İyi & -.24923 & .11332 & .091 \\
\hline & \multirow[t]{2}{*}{ İyi } & Başlangıç & $.69101^{*}$ & .17687 & $.001^{*}$ \\
\hline & & Orta & .24923 & .11332 & .091 \\
\hline
\end{tabular}

${ }^{*} p<0.05$

Aynı bağlamda baba yabancı dil düzeyi orta düzey ile iyi düzey arasında babaları olan çocukların yabancı dil düzeyi iyi düzeyde babası olan çocuklar lehine anlamlı bir fark belirlenmiştir $\left(\mathrm{X}_{\text {ortiyi: }}-10.08673\right.$; $\left.p<.05\right)$. Son olarak, baba yabancı dil düzeyi iyi ile başlangıç seviyesinde olan çocuklar arasında babalarının yabancı dil düzeyi iyi olanlar lehine anlamlı bir fark tespit edilmiştir ( $\mathrm{X}_{\text {ortorta }}$ :-15.56232; $\left.p<0.05 ; \mathrm{X}_{\text {ortiyi }}: 10.08673 ; p<0.05\right)$.

Faktör 1 (kararlılık) boyutunda; baba yabancı dil düzeyi başlangıç düzeyi ile iyi düzey arasındaki çocukların farklılı̆̆ incelendiğinde baba yabancı dil düzeyi iyi düzeyde olanlar lehine anlamlı bir fark ortaya çıkmıştır

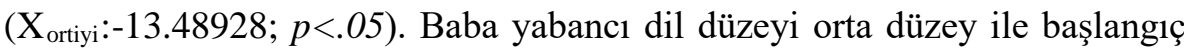
düzey arasında olan çocukların farklılığı incelendiğinde baba yabancı dil

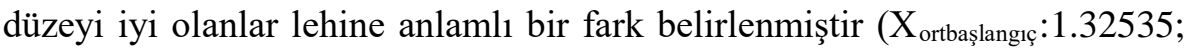


$p<.05)$.

Faktör 2 (isteklilik) boyutunda; baba yabancı dil düzeyi başlangıç düzeyinde olanlar ile baba yabancı dil düzeyi orta olan çocukların yabancı dillere karşı ilgilerinde baba yabancı dil düzeyi orta olanlar lehine anlamlı bir

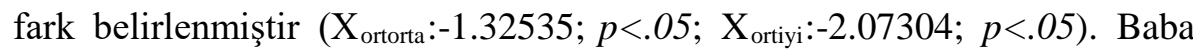
yabancı dil düzeyi başlangıç düzeyinde olanlar ile baba yabancı dil düzeyi yüksek olan çocukların yabancı dillere karşı ilgilerinde baba yabancı dil düzeyi yüksek olanlar lehine anlamlı bir fark belirlenmiştir Aynı şekilde baba yabancı dil düzeyi orta ile iyi düzey arasında ise orta düzey lehine anlamlı bir

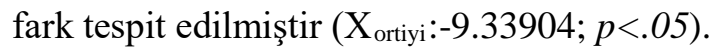

Tablo 8. 60-72 Aylık Çocukların Yabancı Dillere Karşı İlgilerinin Anne Yabancı Dil Düzeylerine İlişskin ANOVA Sonuçları

\begin{tabular}{llccccc}
\hline $\begin{array}{l}\text { Anne Yabancı } \\
\text { Dil Düzeyi }\end{array}$ & $\begin{array}{l}\text { Varyansın } \\
\text { Kaynağı }\end{array}$ & KT & sd & KO & F & $\boldsymbol{p}$ \\
\hline Toplam & Gruplar arası & 6.833 & 2 & 3.416 & & \\
& Gruplar içi & 131.322 & 218 & .602 & 5.671 & $.004^{*}$ \\
& Toplam & 138.154 & 220 & & & \\
\hline Kararl1lık & Gruplar aras1 & 5.998 & 2 & 2.999 & & \\
(Faktör 1) & Gruplar içi & 152.444 & 218 & .699 & 4.288 & .015 \\
& Toplam & 158.442 & 220 & & & \\
\hline İsteklilik & Gruplar aras1 & 17.019 & 2 & 8.509 & & \\
(Faktör 2) & Gruplar içi & 117.127 & 218 & .537 & 15.838 & $.000^{*}$ \\
& Toplam & 134.146 & 220 & & & \\
\hline
\end{tabular}

${ }^{*} p<0.05$

Tablo 8'e göre, 60-72 aylık okul öncesine devam eden çocukların yabancı dillere karşı ilgilerinin anne yabancı dil düzeylerine göre varyans analizi sonuçları incelendiğinde hem toplam puanlarda hem de faktör2: isteklilik boyutunda anlamlı bir farklılık belirlenmiştir (Ft:5.671; $p<0.05$; F2:15.838; $p<0.05$ ). Bu bağlamda 60-72 aylık okul öncesine devam eden çocukların yabancı dillere karşı ilgilerinin anne yabancı dil düzeylerine göre varyans analizi tablosu incelendiğinde, okul öncesine devam eden çocukların anne yabancı dil düzeyleriyle yabancı dile karşı ilgilerinin toplam puanlarda, kararlılık ve isteklilik boyutlarında değişmeler görülmektedir. Bu durumda anne yabancı dil düzeylerindeki farkın anlamlılığını test edebilmek için Scheffe analizi yapılmıştır. 
Tablo 9. 60-72 Aylık Çocukların Yabancı Dillere Karşı İlgilerinin Anne Yabancı Dil Düzeylerine İlişkin Ft, F1 (Kararlılık) ve F2 (İsteklilik) Boyutlarında Scheffe Analizi

\begin{tabular}{|c|c|c|c|c|c|}
\hline $\begin{array}{l}\text { Anne Yabancı } \\
\text { Dil Düzeyi }\end{array}$ & (I) aylık & (J) aylık & $\begin{array}{c}\text { Ort. Fark } \\
\text { (I-J) }\end{array}$ & $\begin{array}{l}\text { Std. } \\
\text { Hata }\end{array}$ & $p$ \\
\hline \multirow{6}{*}{ Toplam } & \multirow[t]{2}{*}{ Başlangıç } & Orta & $-.51541^{*}$ & .15843 & .006 \\
\hline & & İyi & -.29815 & .21356 & .379 \\
\hline & \multirow[t]{2}{*}{ Orta } & Başlangıç & $.51541^{*}$ & .15843 & .006 \\
\hline & & İyi & .21725 & .16638 & .428 \\
\hline & \multirow[t]{2}{*}{ İyi } & Başlangıç & .29815 & .21356 & .379 \\
\hline & & Orta & -.21725 & .16638 & .428 \\
\hline \multirow{6}{*}{$\begin{array}{l}\text { Kararlılık } \\
\text { (Faktör 1) }\end{array}$} & \multirow[t]{2}{*}{ Başlangıç } & Orta & $-.49830^{*}$ & .17070 & $.015 *$ \\
\hline & & İyi & -.38551 & .23010 & .248 \\
\hline & \multirow[t]{2}{*}{ Orta } & Başlangıç & $.49830^{*}$ & .17070 & .015 \\
\hline & & İyi & .11279 & .17926 & .821 \\
\hline & \multirow[t]{2}{*}{ İyi } & Başlangıç & .38551 & .23010 & .248 \\
\hline & & Orta & -.11279 & .17926 & .821 \\
\hline \multirow{6}{*}{$\begin{array}{l}\text { İsteklilik } \\
\text { (Faktör 2) }\end{array}$} & \multirow[t]{2}{*}{ Başlangıç } & Orta & $-.59524^{*}$ & .14962 & $.000 *$ \\
\hline & & İyi & .10952 & .20169 & .863 \\
\hline & \multirow[t]{2}{*}{ Orta } & Başlangıç & $.59524^{*}$ & 14962 & $.000 *$ \\
\hline & & İyi & $-.70476^{*}$ & .15713 & $.000 *$ \\
\hline & \multirow[t]{2}{*}{ İyi } & Başlangıç & -.10952 & .20169 & .863 \\
\hline & & Orta & $.70476^{*}$ & .15713 & $.000 *$ \\
\hline
\end{tabular}

Tablo 9'da görüldüğğ gibi, anne yabancı dil düzeyi başlangıç-orta ve iyi düzeyler karşılaştırıldığında toplam puanda anne yabancı dil düzeyi başlangıç seviyesi ile orta seviyede yabancı dil düzeyinde olan anneler arasında orta seviyedekiler lehine anlamlı bir farklılık göze çarpmaktadır ( $\mathrm{X}_{\mathrm{ba}-}$ sort:-.51541; $p<.05)$. Benzer farklılık "kararlılık" boyutunda da dikkat çekmekte ve anne yabancı dil başlangıç seviyesinde olanlar ile orta seviyede olanlar arasinda orta seviyede yabancı dil seviyesinde olan anneler lehine

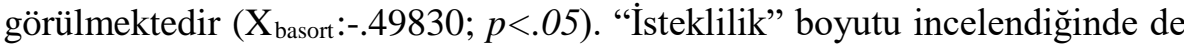
benzer şekilde anne yabancı dil seviyesi "başlangıç" düzeyinde olanlar ile "orta" düzeyde olan anneler arasındaki farklılık "orta" düzeyde yabancı dil seviyesine sâhip anneler lehine ( $\mathrm{X}_{\text {basort }}$-..59524; $\left.p<.05\right)$; "orta” düzeyde yabanc1 dil bilgisine sâhip olan anneler ile "iyi" düzeyde yabancı dil bilgisine 
sâhip olan anneler arasındaki anlamlı farkta "iyi" düzeyde yabancı dil bilgi-

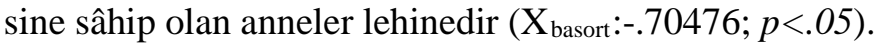

$\mathrm{Bu}$ durumda anne yabancı dil düzeyinin iyi olması çocuğun yabancı dillere olan ilgisini, yabancı dil öğrenmeye karşı olan kararlılığını ve istekliliğini arttırdığı söylenebilir.

Tablo 10. 60-72 Aylık Çocukların Yabancı Dillere Karşı İlgilerinin Ders Saatlerine İlişkin Pearson Analizleri

\begin{tabular}{lccccc}
\hline & $\mathbf{X}_{\text {ort }}$ & ss & $\mathbf{f t}$ & $\begin{array}{c}\mathbf{f 1} \\
\text { (kararlılık) }\end{array}$ & $\begin{array}{c}\mathbf{f} 2 \\
\text { (isteklilik) }\end{array}$ \\
\hline Toplam & 3.6944 & .79245 & & & \\
Kararlılık (Faktör 1) & 3.6826 & .84864 & $.991^{*}$ & & \\
İsteklilik (Faktör 2) & 3.7496 & .78087 & $.726^{*}$ & $.626^{*}$ & \\
Yab. Dil Saati & 2.55 & .955 & $.465^{*}$ & $.459^{*}$ & $.345^{*}$ \\
\hline$p<.001$ & & & & &
\end{tabular}

Tablo 10'da görüldüğü gibi, yabancı dil saati ile toplam puan arasında düşük düzeyde pozitif bir ilişki ( $\left.\mathrm{r}_{\text {toplam }}=.465 ; p<.001\right)$, "kararl111k" boyutunda düşük düzeyde pozitif bir ilişki ( $\left.\mathrm{r}_{\text {kararllık }}=.459 ; p<.001\right)$ ve "isteklilik" boyutunda düşük düzeyde pozitif bir ilişki olduğu saptanmıştır $\left(\mathrm{r}_{\text {isteklilik }}=.345\right.$; $p<.001)$. Bu durumda çocukların yabancı dil öğrenim saatleri arttıkça yabancı dillere karşı ilgilerinin az da olsa arttığı söylenebilir.

\section{Sonuç, Tartışma ve Öneriler}

$\mathrm{Bu}$ araştırmada okul öncesi eğitim kurumuna devam eden 60-72 aylık çocukların yabancı dillere karşı ilgilerinin cinsiyete, yaş grubuna, okul türüne, okul dışında yabancı dil eğitimi alma durumuna, anne-babanın yabancı dil düzeyine, haftada aldığı yabancı dil saat aralığına göre farklılık gösterip göstermediği incelenmiştir.

Araştırmanın yabancı dillere karşı ilginin cinsiyet değişkenine göre farklılığına ilişkin sorusu Bağımsız Grup $t$ Testi ile analiz edilmiş ve cinsiyet değişkeninin yabancı dillere karşı ilgide farklılık yaratmadığı tespit edilmiştir. $\mathrm{Bu}$ durumda çocukların cinsiyetlerinin onların yabancı dillere olan ilgilerinde değişiklik yaratmadığı söylenebilir. Nitekim, Ekizoğlu ve Ekizoğlu'nun anaokulu öğrencileri ile (2011), Çakan'ın (2005) ilköğretim öğrencileriyle yaptıkları araştırmalarda yabancı dil eğitiminin cinsiyete göre farklılaşmadığ 1 tespit edilmiştir. Benzer şekilde Menjivar ve Akhtar'ın (2016) okul öncesi dönem çocuklarıyla yapmış oldukları yabancı dilde kelime öğrenimi ile ilgili 
araştırma sonucunda da cinsiyete ilişkin farklılık olmadığı ortaya çıkmıştır.

Oysaki Voyer ve Voyer'in (2014) ilköğretimden üniversite öğrencilerine kadar olan yaygın eğitim sisteminde okuyan öğrencilerle yaptıkları araştırma sonuçlarında yabancı dil öğreniminde kız öğrenciler lehine anlamlı bir farklılık tespit edilmiştir.

Araştırmanın çocukların yabancı dillere karşı ilgisinde çocukların yaş gruplarının farklılık yaratıp yaratmadığına ilişkin sorusu bağımsız grup $t$ testi ile analiz edildiğinde hem toplam ölçek puanında hem de isteklilik ve kararlılık alt boyutlarında 6 yaş lehine anlamlı bir farklılık tespit edilmiştir. $\mathrm{Bu}$ tespite dayanarak çocukların yabancı dillere karşı ilgilerinin 6 yaş grubunda 5 yaş grubundakilere göre daha fazla olduğu söylenebilir. Bu durumda çocukların yaşla birlikte yabancı dillere karşı ilgilerinin arttı̆̆ı ifade edilebilir. Nitekim Kearney ve Barbour (2015), Dooly ve Masats (2015), Adzija ve Sindik (2014), Brumen (2011), Ekizoğlu ve Ekizoğlu (2011) küçük çocuklarla yapmış oldukları çalışmalarda da okul öncesinde yabancı dil eğitimi alan 3, 4, 5 ve 6 yaşındaki çocukların yaşları büyüdükçe yabancı dilde kazandıkları bilgi ve becerilerinin olumlu gelişme gösterdiğini tespit etmişlerdir. 6 yaş grubundaki çocukların 5 yaş grubundakilere göre öğrenmeye daha açık oldukları, öğrenme konusunda daha kararlı, istekli ve ilgili oldukları düşünülebilir. Bunun nedeni, Healy (1999)'nin de belirttiği gibi 6 yaşla birlikte çocukların nesneleri hatırlama mantığını kavraması ve bellek stratejileri geliştirmeye başlamaları olabilir. Okul öncesi dönem olarak nitelendirilen 3-6 yaş dönemindeki çocuklar bu dönemin sonlarına doğru yani 6 yaşın sonuna doğru her konuda devamlı çaba harcamaya ve çevresinde olup bitenleri ilgi ile seyretmeye çalışmaktadır (Tok, 2001). Nitekim 6 yaş grubundaki çocukların 4-5 yaş grubundaki çocuklara göre yabancı dil edinim düzeyleri daha yüksektir (Peçenek, 2002).

Araştırmada yer alan çocukların yabancı dillere karşı ilgisinde devam ettikleri okul türünün farklılaşma yaratıp yaratmadığına ilişkin yapılan Bağımsız Grup $t$ Testi sonucuna göre hem ölçek toplam puanında hem de isteklilik ve kararlılık alt boyutlarında bir farklılık tespit edilmemiştir. Bu durum çocuğun devlet okuluna ya da özel okula gidip gitmemesinin çocuğun yabancı dillere karşı ilgisine etkisinin olmadığı şeklinde yorumlanabilir. Devlet okuluna ya da özel okula giden çocukların öğretmenlerinin hepsinin benzer okullardan mezun olması, aslında öğretmen açısından bir farklılığın olmaması da bu çocukların ilgilerinde farklılık olmamasının nedeni olarak açıklanabilir. 
Ancak buna rağmen Aktaş ve İşigüzel (2014)'e göre devlet okulunda çalışan öğretmenlerin öz yeterlik algı düzeyleri özel okulda çalışan öğretmenlere göre daha yüksek düzeyde olduğu belirlenmiştir. Bu araştırmaya benzer şekilde ABD'de yapılan araştırmalarda da devlet okulları ile özel okullar arasında da yabancı dil eğitiminin anlamlı bir şekilde farklılaşmadığı tespit edilmiştir (Berg, 2003; Puhafl ve Rhodes, 2011; Quigley, 1991). Bu durumda Türkiye'de ve ABD'de yabancı dil eğitim programlarının devlet ve özel okullarda benzer uygulandığı; ancak saat açısından farklılıklarının olduğu söylenebilir. Ayrıca 5-6 yaş grubu çocukların okul öncesi dönem çocukları olması ve bu çocuklara uygulanan eğitim programı modelleri benzer şekilde esnek ve oyuna dayalı programlar olması da okul türünde farklılaşmamanın olmasının nedeni olarak açıklanabilir.

Araştırmada yer alan çocukların okul dışında da yabancı dil eğitimi almasının yabancı dillere karşı ilgi duymalarında farklılaşma yaratıp yaratmadığına ilişkin Bağımsız Grup $t$ Testi sonuçlarına göre toplam puanda, kararlılık ve isteklilik boyutlarında okul dışında da yabancı dil eğitimi alma yönünde anlamlı bir farklılık olduğu tespit edilmiştir. Bu durumda okul d1şında yabancı dil eğitimi alan çocukların yabancı dillere karşı ilgilerinin daha fazla olduğu ya da yabancı dil eğitimini dışarıdan bir kaynakla aldırmanın çocukların yabancı dillere karşı ilgilerini arttırdığını söylenebilir. Griva ve Sivropoulou (2009) ve Ekizoğlu ve Ekizoğlu (2011) yaptıkları çalışmalarda da okul öncesi kademesinde yabancı dil eğitimi alan çocukların okul dışında yabancı dil eğitimi almayanlara göre yabancı dil bilgi ve becerileri düzeylerinde olumlu gelişmeler kaydettiklerini tespit etmişlerdir. Burada yapılan araştırma ile diğer araştırmalar bu noktada birlikte değerlendirildiğinde dışarıda da yabancı dile maruz kalma saati arttıkça çocuğun daha fazla yeni bir dil öğrenmeye ilgisi artmakta ve bu da çocuğun yabancı dil bilgi ve beceri düzeylerinde artışa sebep olmaktadır.

Araştırmada yer alan çocukların yabancı dillere karşı ilgilerinin baba yabanc1 dil düzeylerine göre varyans analizi ve Scheffe sonuçlarına göre babanın yabancı dil düzeyinin çocukların yabancı dil ilgilerinde toplam ölçek puanında, isteklilik ve kararlılık boyutlarında farklılık yarattı ğı belirlenmiştir. $\mathrm{Bu}$ durumda baba yabancı dil düzeyi ne kadar iyi ise çocukların yabancı dillere ilişkin ilgilerinin de o kadar yüksek olduğu söylenebilir. Griva, Semogloua ve Geladari (2010) ve Adzija ve Sindik (2014)'in yapmış oldukları araştırmalarda da buradaki araştırmaya benzer şekilde babanın yabancı dil 
düzeyi arttıkça çocuklarının da yabancı dil bilgi ve becerileri artmakta olduğunu belirtmişlerdir. Bu durumda babanın yabancı dil bilgi düzeyinin artması ile çocuğun yabancı dillere karşı ilgisinin arttığı ve bununla birlikte bilgi ve beceri düzeyinin de arttığı söylenebilir.

Araştırmada yer alan çocukların yabancı dillere karşı ilgilerinin anne yabancı dil düzeylerine göre varyans analizi ve Scheffe sonuçlarına göre annenin yabancı dil düzeyinin çocukların yabancı dil ilgilerinde toplam ölçek puanında, isteklilik ve kararlılık boyutlarında farklılık yarattığı belirlenmiştir. $\mathrm{Bu}$ durumda anne yabancı dil düzeyinin iyi olması çocuğun yabancı dillere olan ilgisininin, yabancı dil öğrenmeye karşı olan kararlılığını ve istekliliğini arttırdığ1 söylenebilir. Aynı şekilde Lazăr (2014) yaptığ1 araştırmada okul öncesinde yabancı dil eğitimi alan çocukların anne yabancı dil düzeyleri ile çocuklarının yabancı dil öğrenmede gösterdikleri bilgi ve beceri düzeyleri arasında anlamlı bir farklılaşmanın söz konusu olduğunu belirlemişlerdir. Bazı araştırmalar anne-baba yabancı dil düzeyini birlikte ele alarak araştırma planlamışlardır. $\mathrm{Bu}$ araştırmalarda da benzer bulgular ortaya çıkmıştır (Ekizoğlu ve Ekizoğlu, 2011; Koenig, 2012; Tin, 2013). Bu durumda, aynı babanın yabancı dil bilgi düzeyinde olduğu gibi annenin de yabancı dil bilgi düzeyinin artması ile çocuğun yabancı dil öğrenmeye ilgisinin arttığı ve böylece yabancı dilli öğrenme becerisinin geliştiği ifade edilebilir.

Araştırmada yer alan çocukların yabancı dillere karşı olan ilgilerinin okullarında maruz kaldıkları yabancı dil etkinliklerinin saati ile ilişkisine ilişkin Pearson analizi sonucuna göre çocukların yabancı dil ders saati ile yabancı dil etkinliklerine duydukları ilgi arasında pozitif bir ilişki bulunmuştur. Buradan hareketle çocukların yabancı dil etkinliği saatlerinin arttırılması ile yabancı dillere duydukları ilginin de artacağı söylenebilir. Böylece çocukların yeni bir dili öğrenebilme olasılıklarının da artacağı ifade edilebilir.

Yapılan bu araştırma ile cinsiyet ve okul türü dışındaki tüm değişkenlerin çocukların yabancı dil öğrenimine karşı ilgilerinde farklılık yarattığı ortaya çıkmıştır. Değişim yaratan değişkenler tekrar edilecek olursa araştırmada, 5-6 yaş grubu çocuklar karşılaştırıldığında 6 yaş grubu çocukların yabancı dil öğrenmeye daha ilgili oldukları, annenin ve babanın yabancı dil bilme düzeylerinin çocuklarının yabancı dillere olan ilgilerini farklılaştırdığı, yabancı dil eğitimini okul dışındaki ortamlarda almanın çocukların yabancı dillere olan ilgisini arttırdığı ve okul saatlerinde yabancı dil eğitim saatinin artmasının çocukların yabancı dillere karşı olan ilgilerini desteklediği ortaya 
konmuştur.

$\mathrm{Bu}$ bağlamda uygulayıcılara; anne ve babaların yaşlarına bakmaksızın yeni bir dil öğrenme konusunda teşvik edilmesi, çocuklarının evde ve okul dışı aktivitelerinde yabancı dil eğitimini desteklemelerinin sağlanması önerilebilir. Okulda verilen yabancı dil eğitim saatlerinin arttırılmasının yabancı dil öğrenmeye ilişkin ilgiyi arttırması ile ilişkili bulguya dayanarak okul yöneticilerine ve bu konuda görev yapan yetkililere okullarda verilen yabanc1 dil eğitim saatlerinin arttırılması önerilebilir.

Ayrıca bu yöndeki araştırmalar incelendiğinde, okul öncesinde dil öğrenmeye ilişkin yeterli derecede kaynağın olmadığı düşünülmektedir. Erken çocukluk döneminde yeni bir dil öğrenmenin gerekliliği yadsınamadığından bu konudaki araştırmaların zenginleştirilmesi önerilebilir. Bu araştırma 5-6 yaş grubu çocuklarıyla sınırlıdır. Bu nedenle bu tür araştırmaların daha küçük yaştaki çocuklara da uyarlanması önerilebilir. Ayrıca çocukların ilgilerini arttırabilecek yeni programların geliştirilerek bu programların etkililiğinin çocukların ilgilerini çekmesi açısından değerlendirilmesi de ayrıca araştırmac1lara önerilebilir.

\section{Kaynakça}

Adzija, M. ve Sindik, J. (2014). Learning of foreign language in pre-school children: Evaluation methods in kindergarten's environment. Metodički Obzori, 1(19), 48-65.

Ainley, M., Hidi, S. ve Berndorff, D. (2002). Interest, learning, and the psychological processes that mediate their relationship. Journal of Educational Psychology, 94(3), 545-561.

Akdoğan, F. (2004). Yeni projeler 1şı̆̆ında erken yaşta yabancı dil öğretimi. Hasan Ali Yücel Eğitim Fakültesi Dergisi, 2, 97-109.

Akgöz, E. ve Gürsoy, Y. (2014). Turizm eğitiminde yabanc1 dil öğrenme, istek ve kararlılıkları: Selçuk Üniversitesi Beyşehir örneği. Journal of Tourism and Gastronomy Studies, 2(1), 21-29.

Akın, A. ve Arslan, S. (2014). Başarı yönelimleri ile kararlılık arasındaki ilişkiler. Ë̆itim ve Bilim, 39(175), 267-274.

Aktaş, T. ve İşigüzel, B. (2014). Yabancı dil öğretmenlerinin erken yaşta yabancı dil öğretimine ilişkin öz yeterlik algı düzeylerinin değerlendi- 
rilmesi. International Journal of Languages Education and Teaching, 3, 25-39.

Anşin, S. (2006). Çocuklarda yabancı dil öğretimi. Dicle Üniversitesi Ziya Gökalp Eğitim Fakültesi Dergisi, 6, 9-20.

Balaban-Dağal, A. ve Şahenk-Erkan, S. S. (2016). Okul öncesi dönem çocuklarına yönelik yabancı dil ilgi ölçeğini geliştirme çalışması. International Periodical for the Languages, Literature and History of Turkish or Turkic, 11(9), 135-152.

Berg, K. K. (2003). A comprehensive study of the teaching of foreign language at the elementary school level. Yayınlanmamış yüksek lisans tezi, University of Wisconsin, USA.

Bernard, J. (2010). Motivation in foreign language learning: the relationship between classroom activities, motivation, and outcomes in a university language-learning environment. Yayınlanmamış bitirme tezi, Dietrich College of Humanities and Social Sciences, Carnegie Mellon University, USA.

Brumen, M. (2011). The perception of and motivation for foreign language learning in pre-school. Early Child Development and Care, 181(6), 717-732.

Christensen, L. B., Johnson, R. B. ve Turner, L. A. (2015). Araştırma yöntemleri desen ve analiz (2. baskı). (A. Aypay, Çev. Ed.). Ankara: Anı Yayıncılık. (Orijinal çalışma basım tarihi 2014.)

Çakan, M. (2005). Billişsel stiller ile yabancı dil başarısı arasındaki ilişki: 8 . sınıf Fransızca örneği. İlköğretim-Online, 4(1), 53-61.

Demirezen, M. (2003). Yabancı dil ve anadil öğreniminde kritik dönemler. TÖMER Dil Dergisi, 118, 5-15.

Dooly, M. ve Masats, D. (2015). A critical appraisal of foreign language research in content and language integrated learning, young language learners and technology-enhanced language learning published in Spain (2003-2012). Language Teaching, 48(3), 343-372.

Doi: $10.1017 / \mathrm{S} 0261444815000117$.

Dörnyei, Z. (1999). Motivational strategies in the foreign language classroom. London: CILT. 
Ekizoğlu, A. ve Ekizoğlu, N. (2011). The assessment of the English awareness education in kindergarten: An action research. Procedia-Social and Behavioral Sciences, 28, 1011-1019.

Fisher, R. (1990). Teaching children to think. United Kingdom: Basil Blackwell.

Gardner, R. C. ve Lambert, W. E. (1972). The Attitude / Motivation Test Battery-revised manual. London, Ontario: The University of Western Ontario, Language Research Group.

Genç İlter, B. ve Er, S. (2007). Erken yaşta yabancı dil öğretimi üzerine veli ve öğretmen görüşleri. Kastamonu Üniversitesi Kastamonu Eğitim Dergisi, 15(1), 21-30.

Griva, E., Semogloua, K. ve Geladari, A. (2010). Early foreign language learning: Implementation of a project in a game-based context. Procedia Social and Behavioral Sciences, 2, 3700-3705.

Griva, E. ve Sivropoulou, R. (2009). Implementation and evaluation of an early foreign language learning project in kindergarten. Early Childhood Education Journal, 37, 79-87.

Doi: 10.1007/s10643-009-0314-3.

Halliwel, S. (1993). Teaching English in the primary classroom. London: Longman.

Healy, J. (1999). Çocuğunuzun gelişen aklı. İstanbul: Boyner Holding Yayınları.

Juriševič, M. ve Pižorn, K. (2013). Young foreign language learners' motivation-a Slovenian experience. Porta Linguarum, 19, 179-198.

Kara, Ş. (2004). Ana dil edinimi ve erken yaşta yabancı dil öğretimi. Uludă̆ Üniversitesi Eğitim Fakültesi Dergisi, 17(2), 295-314.

Karasar, N. (2014). Bilimsel araştırma yöntemleri (27. baskı). Ankara: Nobel Yayın Dağıtım.

Kearney, E. ve Barbour, A. (2015). Embracing, contesting and negotiating new languages: Young children's early socialization into foreign language learning. Linguistics and Education, 31, 159-173. 
Koenig, M. (2012). Toddlers learn words in a foreign language: The role of native vocabulary knowledge. Journal Child Language, 39, 322-337. Doi: $10.1017 /$ S0305000911000067.

Küçükoğlu, A., Kaya, İ. ve Turan, A. (2010). Sınıf öğretmenliği ABD öğrencilerinin başarı yönelimi algılarının farklı değişkenler açısından incelenmesi (Atatürk Üniversitesi ve Ondokuz Mayıs Üniversitesi örneği). Fırat Üniversitesi Sosyal Bilimler Dergisi, 20(2), 121-135.

Lazăr, A. (2014). Pre-primary educators and the use of digital resources to raise early foreign language awareness. Procedia-Social and Behavioral Sciences, 180, 841-846.

Doi: 10.1016/j.sbspro.2015.02.221.

MacIntyre, P. D. ve Blackie, R. A. (2012). Action control, motivated strategies and integrative motivation as predictors of language learning affect and the intention to continue learning. French System, 40, 533-543.

Menjivar, J. ve Akhtar, N. (2016). Language experience and preschoolers' foreign word learning. Bilingualism: Language and Cognition, 20(3), 1-7.

Mihaljevic-Djigunovic, J. (2012). Attitudes and motivation in early foreign language learning. CEPS Journal, 2(3), 55-74.

Mirici, İ. H. (2001). Çocuklara yabancı dil öğretimi. Ankara: Gazi Kitabevi.

Mirici, İ. H., Metin, G., Efe, K. ve Akınc1, S. (2002, Haziran). Teaching English through dramatisation in pre-school education. The First International Troia-Çanakkale Language Teaching and School Development Symposium. Çanakkale Onsekiz Mart Üniversitesi, Çanakkale.

Oxford, R. L. ve Shearin, J. (1994) Language learning motivation: Expanding the theoretical framework. Modern Language Journal, 78(1), 12-28.

Özcan, H. (2008). Küreselleşme sürecinde ulusal dil, yabancı dil ve farklı türlerde kültürlerarası içerikli metinler üzerine düşünceler. Dokuz Eylül Üniversitesi Buca Eğitim Fakültesi Dergisi, 24, 54-68.

Peçenek, D. (2002). 4-6 yaş grubu Türk çocuklarının İngilizce öğrenme süreçleri üzerine bir durum çalışması. Yayınlanmamış doktora tezi, Ankara Üniversitesi Sosyal Bilimler Enstitüsü. 
Puhafl, I. ve Rhodes, N. C. (2011). Foreign language instruction in U.S. Schools: Results of a national survey of elementary and secondary schools. Foreign Language Annals, 44(2), 258-288.

Quigley, E. G. (1991). Foreign language teaching in primary schools: Issues and research. Dublin: Irish National Teachers' Organisation Head Office.

Roth, G. (1998). Teaching very young children pre school and early primary. London: Richmond Publishing.

Schmidt, R., Boraie, D. ve Kassabgy, O. (1996). Foreign language motivation: Internal structure and external connections. R. Oxford, (Ed.). Language Learning Motivation: Pathways to the New Century (Technical Report \#11) içinde (9-70). Honolulu: University of Hawai'i, Second Language Teaching \& Curriculum Center.

Sevinç, M. (2003). Erken çocuklukta gelişim ve eğitimde yeni yaklaşımlar. İstanbul: Morpa Kültür Yayınları.

Soyupek, H. (2007). Yabancı dil öğretiminde güdülemenin önemi. ICANAS 38 Uluslararası Asya ve Afrika Çalışmaları Kongresi, Ankara.

Tin, T. B. (2013). Exploring the development of "interest" in learning English as a foreign/second language. RELC Journal, 44(2), 129-146.

Doi: $10.1177 / 0033688213488388$.

Tok, F. (2001). Çocuğun gelişiminde okul öncesi eğitim. İstanbul: Kariyer Yayıncilik.

Turanl1, M. ve Güriş, S. (2010). Temel istatistik (3. bask1). İstanbul: Der Yayınları.

Uslu, Z. ve Özpek, Y. (2014). Yabancı dil öğretmeni adaylarının ikinci yabancı dili öğrenmeye ilişkin tutum ve görüşleri. Hasan Ali Yücel Eğitim Fakültesi Dergisi, 2, 129-140.

Voyer, D. ve Voyer, S. D. (2014). Gender differences in scholastic achivement: A meta-analysis. Psychological Bulletin, 140(4), 1174-1204.

Yazıc1, Z. (2002). Okul öncesi eğitimin okul olgunluğu üzerine etkisinin incelenmesi. Milli Eğitim Dergisi, 155-156, http://dhgm.meb.gov.tr/yayimlar/dergiler/milli_egitim_dergisi/155-15 6/yazici.htm. 